\title{
digitalEDUCATION
}

\section{How to assess A meaningful technology-integrated tool for the reflective educators}

\author{
Giuseppe Annacontini \\ giuseppe.annacontini@unisalento.it \\ University of Salento, Italy

\section{Anna Paola Paiano} \\ annapaola.paiano@unisalento.it \\ University of Salento, Italy
}

\begin{abstract}
In this paper we intend to present a tool for self-assess, support and improve reflective thinking in the educators towards the use of digital storytelling. First, we present an overview on the theoretical framework for conceptualizing a reflective educator, who needs to have a conscious approach on the practice and inquiries on the ethical consideration and important outcomes of teaching practice, with self-reflection, deep analysis of personal beliefs, and expectations on men and women and potential in general, and on learning. educators' expectations are self-generating, and often hard to be changed. Moreover, educators stay trapped in unexamined rulings, judgements, interpretations, conventions, potentials and hopes. Second, we describe the process of constructing a DST for approaching to the reflective practice infusing personal beliefs and values into a professional identity. Third, we describe the process of constructing the rubric, its elements, indicators and levels to value the product every educator made. We conclude with the self-assessment tool we want to propose in our on-going research project.
\end{abstract}

\section{Keywords}

reflective educator, personal Digital Storytelling, self-assess, rubric. 


\section{Regarding skills for a reflective professionalism}

In training of educators and in educational practice, times and spaces used to respond to the primarey need to be able to return to the actions carried out, in order to observe and initiate a reflection that gives back the sense of "applied technique" rather than "Strategy pursued" become unavoidable skills Where reflexivity is interpreted as a "form of heuristic-reflective rationality", a set of useful to "contextually re-think one's actions [...], its theoretical and practical and ideological foundations and put it back into focus" (Cambi, 2006).

The reflection on the matter becomes a condition to facilitate the adherence to a model of practice as a strategic action able to concretize the educational intention to produce improvements in reference to the cure for the double bond of self-realization and socialization of the subjects in training, infinite integration of the self and the world. It is here that a strong identity trait of the educational profession is played, it is advisable to be cultivated in advance in such a way that it can accompany itself throughout the duration of its own continuous redefinition. The absence of the ability to reflect about and in regard of the experience would risk paradoxically to make the educator lose contact with reality and the practices themselves that, although they may be carriers and generators of knowledge, remain bound to their empirical origins, to a specific type of social representation and a mainly normative meaning, self-validating and self-affirming themselves. The knowledge related to pure praxis "even when they are elaborated reflexively, rarely reach the level of critical awareness, and their profile [...] makes them fall into dogmatic forms. There is therefore the need for an elaboration that is not only reflective but also critical" (Baldacci 2016, p.51). Donald Schön, in his "Reflective Practitioner", had moreover specified that when we talk about professionalism, we always refer to a "form of research". Reflective professionals are those able to be "researchers in a practical context", because through their tasks and their professional practices they modify, expand, improve, build and co-construct knowledge.

Reflective professional action implies, in this perspective, the establishment of an "epistemology of personal knowledge" based on the idea of a subject that is proactive and participant in his own development process, also capable of building knowledge and acting to change reality, able to monitor his own ability to think and act (Polanyi, 1990).

Reflexivity allows to work generally on professional qualities focusing attention on different dimensions of action and human feeling (cognitive, emotional-affective, social-relational in the first place) but its relevance becomes exemplary for the specific educational field, as it it proves, open to the redefinitions of its own structures, of its values, its representations and even of the imaginaries that accompany the idea of education-education-training by reason of the mobile and iridescent way of entering into relation of the different fields of knowledge, communication of different social and cultural worlds, transformation of the different evolutionary models of societies, economies, politics.

Both for educators in service and for those in training, acting reflexively means starting from the problematization of knowledge, naturally turning to the public and cultural (political and economic) meanings of the relationship between knowledge-professionality-social world. Thus reflexivity implies the careful consideration (cure) of the attitudes and postures of one's own and of others which corresponds to a new representation of the self and the other that often make for the first time aware of new and unprecedented training needs. 
This type of experience translates in an original way Mezirow's sense of development of a "changed conceptual perspective", accessible through narrative and meaningful learning addressed to a new awareness that is rooted in the experience of the reflective quality of a narration that is structured as a game of mutual recognition between "narrated self" and "self as other", or the ability to look at the "professional tradition" with a sense of wonder or, why not, to complete that particular experience of the unexpected - of the already known as unprecedented and unexpected - that pushes to elaborate and to give body to the desire to overcome this condition and return to recognize, at least temporarily, in the image produced "by the mirror"of the narration.

In this dynamic of the "narrative mirror", it is possible to start a practice that tends to harmonize narrated-self and desired-self through the recognized self, and the need to know how to use and activate the dialogic (not mono-logical), problematic (not dogmatic or sceptical), complex (nonreductive) potentials proper to any subjectivity. In other words, it needs to regain and take on that "agonal disposition"typical of every attempt at mediation and recomposition as well as for a fixed term (Colli 1992, Annacontini 2017) of the inheritance and non-existent, as the construction of a median platform that welcomes the past and future perspectives of subjectivity. It requires a tight and continuous dialogue between the cultural and professional dimension, knowing how to take the perspective of others, knowing how to look at one's own experiential tradition with different and unusual eyes, the ability to modify and reshape one's own habits and learn from each other new elements of professionalism.

In narrative practice we must first distinguish between effects aimed at promoting "reflexivity" from those aimed at promoting "reflective attitudes" and "reflective practice" as:

- the former takes the traits of a controlled and intentioned process aimed at knowledge based on a broad and complex network of constraints and relationships, the result of which is a perspective of meaning attributable to the singular actions, in turn being able to produce new ones and such enable us to produce an interpretation of experiences by which we can define the order of the reasons for "why we act" in a certain way and not in another. Thanks to the reflection, the experience is translated into a new visibility, which brings to completion a process of progressive acquisition of awareness. In this way it has been achieved change and improvement of the professional (and education) no less than the community to which it belongs, because of the necessary confrontation with repeated and continuous "identity crises" that free them from the risk of dogmatic falls;

- the latter are mostly traits of spontaneous, occasional and non-systematic events, and lead the subject to confront the "reflexive reasons" of a practice in a discontinuous manner, leaving little possibility for an epiphany to be matched. a conscious change in professional action (Holborn et al., 1992);

- the third is defined as a consolidated attitude aimed at establishing an analytical recognition of the practices regardless of the contingent presence of previous unsatisfactory obstacles, difficulties or experiences. thus the reflexive practice as part of the identity of a professional (Altet 1994; Perrenoud 2001) takes the characteristics of the ability to know how to use previous experiences, being able to insert data and information useful to formalize "knowledge of action" (Schön, 1993) which are the result of taking a distance from the practice. In this sense, the "reflective practice" refers to what can be traced back to the result of a reflexively mediated act and which, in this way, has been able to produce concretely implemented models, strategies, processes and procedures. 
There is a clear separation between "reflective attitude" and "reflexivity" (Schön 1993, SaintArnaud, 1992), while "reflective practice" maintains a close relationship with the latter (Perrenoud, 2001) as it presupposes a habit to intervene transformatively and to have effects in the daily exercise of a profession, far beyond the "theoretical" declarations of intent.

The reflexive practice builds, de facto, a new knowledge "not without critical scope" and effects on action, result of the cyclical reflective relationship between emotionality, thought and transformative action, useful to give new meaning to the problematic world.

\section{Self, others and project}

If we were, trying to make a synthesis, to trace the main areas of reflective practice involved in narrative practice we could surely find:

- the area of the self, referable to the ability to recognize and manage one's thoughts, emotions and actions;

- the area of relationship, referable to the ability to recognize and manage others' thoughts, emotions and actions;

- - the area of planning, linked to the ability to foreshadow possible scenarios and brouidentities and relevant action plans.

These are abilities with a clear hermeneutical matrix that allow us to stay "within situations", to exercise that cognitive and emotional bilocation that allows us to question and understand everyday's life, "to become aware of why and how we act, to question the environment, norms and reference values, to converse with the problematic" (Rossi, 2011, p 205).

These are narrative and reflective abilities that allow "intercepting senses, sharing emotions, forming languages, codifying and spreading knowledge, reference cultures, values that both declared and inscribed in artefacts, tacit and widespread assumptions, they require the care of processes related to organizing contexts and practices of reflective action in order to learn from their experience in a transformative perspective" (Scaratti, Stoppini, Zucchermaglio, 2009, pp. 2829).

In the proposed vision of narrative practices as "reflective action context and practice", the skills of recognition and management of emotional shades are linked to each phase of such experiences are important. It is about introducing one's ability to understand the nature, the causes and the possibilities of control and expression of emotions (Pons and Harris, 2000; (Pons and Doudin, 2000) recognizing contemporaneously how such knowledge is eminently historical, linked to the ability to evolve according to the possibilities that everyday experiences (including narrative) offer us (Harris, 1991, translation, 1983, Harris et all., 1981) to gradually acquire a clearer awareness and skill in coping with the frustrating obstacles and generating anxiety.

If this is true, we could say that if in the production of the narrative and in its subsequent fruition this emotional quality (and relative competence) is missing, it would probably be incapable of activating the process of self-reconstruction that accompanies the idea of a reflexive (and metacognitive) action to support, as Saarni says (1999), the experiences of self-efficacy (selfefficacy) of the individual in social transactions - Dewey put the suggestion (which strictly speaking is an emotional tonality) above any reflexive action -. 
The emotional quality of the narratives goes hand in hand with a broader self-awareness that can help verify the progress of one's thinking, not only to observe it in order to optimize it.

Thus, in the story narrated resides the possibility of developing self-awareness as "understanding through the interpretation"of a represented self, charged with the past and facing a planning future that can be explicitly thematized.

In the storytelling we can rediscover the "dialogue that we are" between past and future, between the self and the world (Gadamer, 2001) even when everyday life leads us to a "different" life, to passages and existential turns different from the constructed identities which, for this reason, are not necessarily only undesirable or incomprehensible but can be opportunities to weave a new existential plot.

It is a matter of welcoming, in the act of storytelling, the same narrative nature of the identity that we have been - we are - we will be, and thus embody the sense of being and become a woven and complex historical identity. An identity that autopoietically combines constancy-organizational closure and flexibility-structural openness, an identity that, at Savikas "supports uniformity and [...] takes into account the change, placing itself again within the social space"(Savickas, 2014, p.31).

Therefore, for what has been said so far, in a completely temporary and exploratory way, we can consider a series of reflective skills that fall within the field of metacognitive training and that narrative practice can allow to develop.

\begin{tabular}{|l|l|l|l|}
\hline & Self Area & Relationship Area & Planning Area \\
\hline Self-Awareness & $\mathrm{X}$ & & \\
\hline $\begin{array}{l}\text { Recognition } \\
\text { emotions }\end{array}$ & $\mathrm{X}$ & $\mathrm{X}$ & \\
\hline $\begin{array}{l}\text { Management of } \\
\text { emotions }\end{array}$ & $\mathrm{X}$ & $\mathrm{X}$ & \\
\hline Neoteny & $\mathrm{X}$ & $\mathrm{X}$ & $\mathrm{X}$ \\
\hline Locus of control & $\mathrm{X}$ & $\mathrm{X}$ & $\mathrm{X}$ \\
\hline Stability & $\mathrm{X}$ & & \\
\hline Handle the failure & & $\mathrm{X}$ & $\mathrm{X}$ \\
\hline Previsional skills & $\mathrm{X}$ & & $\mathrm{X}$ \\
\hline Inellectualization & & & $\mathrm{X}$ \\
\hline Self-efficacy & $\mathrm{X}$ & $\mathrm{X}$ \\
\hline
\end{tabular}

Table 1.

It is important to note, in advance, the shrewdness to read this scheme and the proposed distribution as a simplification, so to speak, for educational purpose. We can try to identify some area of dominance for certain skills, but we must always be aware of the necessary transversal implications for each of them 


\section{a. Self-awareness}

The term self-awareness, as distinct from consciousness, finds its classic definition in the work of Mead (1972) for which the main difference was in the external address of the ability to focus the attention of the latter, as opposed to the internal address of self-awareness. Thanks to Duval and Wicklund (1972) this term has taken on the added significance of being active operators of the ability to identify, process and store information about the self. In fact, if we were to proceed with a more in-depth analysis, the implications that each one of them has with all the areas indicated would necessarily be brought to the fore. In the same way, each competence maintains close correlations with the others, sometimes of dependency, others of correlation or even of an inclusive nature. Therefore, the pattern listed is a simplification tool related to the specific purpose of structuring a self-assessment tool. this is the ability to reflect not so much on experience as on the ability to do and process experience and what originates from it. The complexity that shines through this synthetic definition of the construct self-awareness makes the list of the dimensions of the self that can be involved in the process of self-awareness extremely far wide (Bem-Artzi, Mikulincer, Glaubman, 1995): from the emotional to the cognitive, from the relational to the character, from the psychological to the ethics etc. Furthermore, self-awareness can be thought of in reference to numerous "corollaries" (Morin, 2011) such as agency, theory-of-mind, selfdescription, self-evaluation, self-regulation, self-esteem, the awareness of death and others. In these processes and in these practices the ego has the opportunity to develop a sense of continuity, of permanence, which configures as a sense of the self, historically consistent, which flows, in its highest degree, into the "meta-self-awareness", or be aware of being self-aware (Morin 2011).

\section{b. Recognition of emotions}

The construction of a personal narrative is an experience that is accompanied by different forms of emotional transport that go without too much difficulty from identification to denial, from involvement to distance, from playful fun to the sense of deep annoyance and discomfort. The narration is a technical act (the structured construction of a story) cognitive (which forces to organize the thought) that necessarily consists of a continuous and ineludibly emotional soundtrack. The aim is to become aware of this important presence and, in particular, to make this capacity of recognition one of the essential skills in defining one's self as, knowing oneself better is the basis for a better relationship with others starting from, even in this case, being able to recognize others' emotional states. Knowing how to recognize one's own and others' emotions, beyond the personal talent one can have, means having the potential to connect with others (Gardner, 1983; Gardner\&Hatch, 1989) cultivating the art of relationship.

The narrative action must be considered starting from this dimension, as the ability to recognize one's and others' emotions becomes the competence of developing intimacy and relationships with others. Goleman (1997) referred to awareness as the basic ability to control the evolution of one's life. In the same way, Shapiro (1998) identifies in this skill a preparatory variable to the development of emotional control. The personal narration responds to these characteristics if it puts its author in a position to look at his own thoughts and feelings connected to the past narrated event and to the experience that in the "hic et nunc" is being made of the same event. 


\section{c. Management of emotions}

The recognition of emotions is the introduction of the more detailed management skills of the same. Goleman defines the art of emotional self-control as the "ability to motivate oneself and to persist in pursuing a goal in spite of frustrations; to control impulses and gratifications" (1996, p.54). The management of emotions starts from the analysis of one's own limits and possibilities, from skills in reading people and contexts to anticipate events and orient them, "stabilizing" awareness about our immediate experience (Bennet\&Goleman, 2001). The careful and conscious management of emotions become for Dato (2004) a cognitive catalyst since we learn to put the emotions to the system with reason and to develop an attentive and sensitive mind focused on finding alternative solutions, controlling "sensory data, thoughts related to emotions and their behavior" (p.35).

Therefore, narrating one's story is an action that is pedagogically evaluated with reference to the ability to develop "self-mastery", that is to develop the ability to control "the impulses and the disturbance $[\ldots]$, to be honest with oneself and with others, to take responsibility for their obligations, to be flexible to change and open to new ideas and projects" (p.36). It is clear, as Richburg and Fletcher (2002) recalled, how there is an essential relationship between social management skills and emotional awareness of oneself.

\section{d. Neoteny}

Neoteny indicates that process of phylogenetic development that causes juvenile states of subjects from previous generations to become the adult states of the successive generations (Gould, 2013). This involves, especially in the case of man, the establishment of that species-specific predisposition to always learn "as"being always young. However, both the phylogenetic affirmation of this quality and its ontogenetic manifestation does not take place in the void; on the contrary, Morin (1974) has proposed a model (called "anti-model") that binds cerebralization-youthfulness and development of cultural and social complexity. This, to make clear the recursions between the organizational levels of self-development and self-reproduction of the socio-cultural system. In order to optimize the neotenics skills of man it may be necessary to structure opportunities to experiment as much as possible the "juvenile" specificity of species in the forms of leisure activity, sense of wonder, experience of disorientation, etc.

All this for the simple reason that the quality of these experiences opens naturally to the possible, the demonic, the protean (Bertin, 1987). Neoteny, as the quality of the human being and of his continual planning, must be cultivated by offering opportunities to formulate theories about one's being and becoming; in order to experience the crisis and the re-launch of perceptual habits, to have and experience the harmonic polyphony of knowledge, media, content (Baldacci, 2014) that characterize the personal and projectual being of each subject.

\section{e. Locus of control}

With locus of control we refer to an emotional-motivational variable of training and learning processes able to directly influence the motivation of the subject in formation. Its definition was possible starting from the formulation of Weiner's attribution theory (1985), as a basis for defining precisely the construct of locus of control and hypothesizing a direct correlation between the 
attitude that each subject will face in front of a task and the type of attributional analysis that they operate with respect to the causes of success or failure of the singular actions undertaken. These attribution styles refer to the habit of recognizing a direct responsibility for the outcome of an action (whether successful or unsuccessful) due to internal factors - for example related to invested energy or commitment to the task - or external factors - related to the risk or indications offered by subsidiaries or support groups - (Herrmann et al 2002; Flammer, 1995). It becomes important to understand when using certain teaching tools, or in accessing certain situations/training environments, there is an opportune push to recognize, on the part of the acting subject, how to undertake an action part of the potential for success depends on the personal commitment. It is equally evident that in order to correctly attribute the causes of the results of their actions, it is necessary to have adequate knowledge and understanding of the contextual variables involved in it, as well as the ability to operate adequate control over them. This means that the greater the knowledge of the self and of the inhabited world, the more precise the attributions made and, respectively, the effects of these attributions will be.

\section{f. Stability}

The stability of the causes in relation to actions that may result in success or failure is another particularly important dimension to take into consideration. This is because depending on whether a cause is considered stable or not - depending on whether it is considered as dependent or independent, not only because of its internal/external nature but also because of the amount of investment each individual can be responsible for- there is the possibility of action to improve considerably the outcome of the performances (Weiner, 1985). It is not the same thing to identify the causes of a failure in a stable factor, on which the individual can have no effect because it is invariant or unstable, on which his determination can lead to a change and this leads to the further "corollary" of the control, ie the recognition of how the decision on "how much effort to dedicate to a task" is ultimately individual responsibility and, therefore, is a variable on which to intervene. Regarding the relationship with the environment, for these two dimensions the same considerations as for the locus of control are valid, it must be underlined that, naturally, the design perspective is a fundamental activator of control skills and, therefore, of investment in a action in order to achieve its fulfillment or, in other words, motivation as the underlying reason for behavior (Anolli, Legrenzi 2001, Guay et al 2010, Broussard\&Garrison, 2004).

\section{g. Handle the failure}

In many cases personal storytelling can be an opportunity to refine and to expand the singular skills in managing failures and thereby it become an opportunity for the expansion of subjective potential. A definition that describes with good approximation the competence that we intend to suggest is "coping", the "adaptation strategy" that implies the activation of one's cognitive processes aimed to orient the singular conduct focused at solving a problem. Specifically, Folkman and Lazarus have defined coping as the attempt to handle problematic situations caused by stressful events experienced as threatening or harmful, regardless of the personal resources available at that time the subject dealt with them (Folkman \& Lazarus, 1980; Lazarus, 2006, 2007). When among the past experiences there were times when one was not able to deal with stressful situations, the attention of the personal narrative of the same situations or experiences 
will focus on the modalities to be implemented to change the approach we have towards the world starting from the review of personal, relational and environmental resources available to realize one's personal life project. Narrative must increase subjective potential in terms of resilience strategies, positive adaptation, or survival experiencing (Wald J., Taylor S., Asmundson G. J. G., et al., 2006). This is possible to the extent that it helps to focus on the conditions of change/crisis that have shaped the problem and that it is assumed can also be addressed to allow a general reconfiguration of the situation and, thus, manage the problematic situation also helping to recalibrate the emotional response in relation to the desired results in terms of well-being. Narrative work, as a process and as a product that the subject performs, becomes an occasion not to incur in coarse errors related to the momentary incapacity to deal with unexpectedly stressful situations, on the contrary, it puts on the conditions to more effectively regulate the individual's resources and responses to problematic situation.

\section{h. Previsional skills}

The narrative work, effectively combining mastery, management and reflexivity, opens a competence in recognizing opportunities and expanding alternatives defined as primary. It is a competence with clear planning intent, the possibility and ability to exercise not only a vigilant focus on one's own present but also a forecast opening for the future. The task entrusted to the subject is to learn how to mediate the sense of reality with the sense of possibility where the design competence pertains to the "theory of decisions" (Zonca, 2004), helping to investigate the complexity of situations so that we can take actions as effective as possible. The personal narration must allow its author to think differently and thus develop a "positive thinkability" that is "realized when the subject can think of himself (with positive foreshadowing) in a different situation from the current one (new possibilities) [...]. Positive prefiguration is not an object of simple fantasy but an object of construction"(Bruscaglioni 1994, p.138). In this way the quality of narrative action is commensurate with the development of the ability to narrate the possible (Batini\&Del Sarto, 2007) to think about the unimaginable, to deny one's present as a given and to face unique events that transgress the rules of daily, developing the sense of possible and desire, imagining future worlds and activating resources to be able to build them with others, or accurately mediating a sense of possibility and reality.

\section{i. Intellectualization}

Intellectualization is one of the qualities that a reflexive narrative action must absolutely have. The characteristic in question consists in the "definition of the problem". Specifically, a training action must be able to put the subject, who previously lived in a state of generalized and indistinct discomfort, in the condition of identifying, locating and defining the problem. It is a matter of promoting analytical and descriptive skills (construction and reconfiguration) of the experience in question, through the practice of objectification and distancing which, for example, can be used to interpret a fresco as a whole." (Rodgers, 2002) As Dewey says, in so doing, the emotional condition linked to the previously experienced discomfort can now become an articulated idea and an object of thought: "There is a process of intellectualization what at first is an emotional quality of the whole situation. This conversion is effected by noting the conditions that constitute the trouble" (1965, p.108). The reflective quality of a narrative action is linked to its ability to become 
a promoter of thought through the action of mirroring the perturbed emotional state that led to the search for training in a problem that, once defined, can at least be recognized and therefore dealt with as a "Me-World" transitional relationship. This is the issue of promoting a rereading that has nothing casual or accidental but is a specific analytical arrangement of knowing how to think and represent concrete situations and emotions regardless of the beliefs possessed by the individual subject.

In the last analysis, the narration must restore the completeness and complexity of the lived situation, thanks to which it is possible to correctly formulate a problem and the relative questions useful to solve it in planning and self-realization direction.

\section{j.Self-efficacy}

Self-efficacy has been defined within the studies known as Socio-cognitive Theory (Bandura 1986a, 1986b) as a mechanism of primary importance in allowing to act effectively in the face of important issues, putting together in the best possible way both personal potentials and contextual opportunities. This means that self-efficacy is a fundamental vector to guarantee the individual to act actively in order to propitiate the occurrence of desired events in relation to certain objectives that can be established individually (Bandura, 2001). The levels, strength and generalization (Bandura, 1986) of self-efficacy are not given once for, they are structured according to four variables related to the possibility of direct experience of one's ability to master situations (mastery experiences); the ability of others to deal with these situations in order to develop new skills (vicarious experiences); in the presence of acts of persuasion/encouragement that may lead to believe that they can deal with specific situations; the ability to interpret one's emotional and physiological states (Bandura 1986a). The self-efficacy of a subject tells us a lot about his agentive and transformative competence and, for this reason, on how it can arrange itself for a project that requires the activation of specific potentials not necessarily previously possessed by the subject. This future-planning horizon becomes the specific context outside which the concept of self-efficacy cannot be considered (or rather it loses much of its interest). By its very definition, self-efficacy is specifically related to the context and the desire to achieve important results.

\section{A meaningful technology-integrated methodology: from the theory to the practice.}

As Annacontini declares in the previous paragraphs, "reflexivity", "reflective attitudes" and "reflective practice" are usually described as important features of skilled educators who used the experience to learn in a critical way how to develop and maintain competence across a practice lifetime. The critical reflection on experience and practice would enable recognition of learning requirements (Schön 1983; Boud et al. 1985), for example, as one's professional identity is developed, or features of learning related on personal beliefs, attitudes and values, in the context and in the professional culture.

The reflective approach offer a way of integration of all these conditions. furthermore, the use of reflective thinking would be aimed to develop a professional who is self-aware and able to selfmonitoring and self-regulation (Bandura, 1986). And that is why we introduce reflective 
practitioners that use reflective thinking as a tool for revisiting and understanding their actions and experience to learn from it and for summarize and clarify the complexity of the practice. In the same way, reflective professionals, also for educators and educators, manage to build a community of professional, encouraging each others to achieve a critical control over the more intuitive features of the experience.

As emphasized in the Vygotskyan's theory (1978) the interaction between peers play an important role as social roots of knowledge. Based on the costructivism belief that knowledge construction is a shared experience "by the dialectical interplay of many minds, not just one mind"(Goodman, 1986 , p. 87), the reflective thinking involves social interactions as need of multiple perspectives and feedback on one's own performance and understanding.

Often, reflection occurs when knowledge was used in the past and when it might be useful in the future (Salomon\&Perkins, 1989), and this could be the first step towards reflective practice in a educators training: moving from the reconstruction of personal formative biography and enabling the skills to recognize and be able to tell, with a reflexive and critical look, the learning aims but also the values and meanings related the experience.

In the era of accelleration, caracterized in the first paragraph, there are dimensions and conditions on which the narrative "habit" is totally absent, for lack of time and moreover for a feeling of shame. Even in the educational professional figures globes, it is rarely considered relevant to recount the educators or educators'knowledge, or to talk about self-awareness, or to frame communities of practices and to focus on the ways in which assessment is carried out, or the pedagogical principle of the planning etc., but it could be necessary to 'storify' this aspects, to reconstrunct the memory and personal path and, moreover, it is necessary to became the own designer of own personal professional identity, so, once understood, interpreted and transformed all this items, they could be related to professional practice also in relation to the framework of institutional transformations (Calvani, 2011). The autobiographical storytelling must be performed as a matter of personal development for educators, oriented to increase their skills for introspective analysis and acquire a greater and better awareness of personal and professional self situation.

Narrative skill is the basis of the reflexive professional's ability to learn from the educational experience (Schön, 1993, p 301), so, the storytelling is a critical reflection with a triple value: on training, on professional and on personal life. When we, as research team, decided to use the storytelling, in particular the personal digital storytelling, to investigate how the reflective thinking is necessary to build the professional identity, we design a rubric for the self assessment useful to focus on those aspects, related to the professional skills, usually not involved in the professional evaluation.

It is, therefore, a preliminary assessment of the usefulness of formative paths based on storytelling and, therefore, aimed at the encounter with otherness, starting from the other that dwells in the very depth of one's own identity and often remains unknown and un-recognized. Starting from this more hidden self, made explicit by the reconstruction of their experience as educators and educators, it becomes possible and simpler to compare each other, through the structuring of environments and the promotion of moments of socialization of stories about their own experience (Cassani \& Fontana, 2000, pp. 69-70). The educators, during the process of self-narration - which is not easy - have to open themselves to deeper dialogue with the other, starting from the awareness and comparison of the projections of one's own "to have been", "being"and "wanting to be". 
As we expressed before, the activity of storytelling is an excellent device related to the practices for the promotion of experience of learning processes especially in the professional sphere, as based on subjectivity and the irreducible uniqueness of the history of life of the individual.

Storytelling means to construct meaning and "it is evident [...] that the competence in the construction and comprehension of stories is essential for the construction of our life" (Bruner, 1997, p.52) also professional. Precisely the absolute importance of this practice and, therefore, of the knowledge and skills that make it possible, obliges pedagogy to reflect on the responsibility of the institutions and training institutions (schools, educational agencies, universities) in "cultivating the narrative ability, develop it, stop giving it for granted", because of it is true that we relate to and always relate through a narration, it is equally true that a big effort is required to understand "how to swim in the sea of stories "(Ivi, 162).

It is necessary taking into account that educators have an adult identity, structured, mostly consolidated as a mentality and interpretative structures and the use of storytelling wants to turn the visions of different epistemological worlds to give way to a process for the reconstruction of new meanings (Cambi, 2006).

In light of what has been said, the practice of storytelling would be a particularly appropriate method to develop the narrative skill necessary to "relate and to tell about the professional self, the must be, the must become of the reflective educator, in his action and practice"(Paquay, 2006, p 46). In fact, the opportunity the specific competence of the "continuous and daily questioning of the educator" and with it the "ability to make enlightened decisions following the events of the day" can became stronger and stronger. (Ivi, p.71). To proceed with reflective work, we need a methodological tool that is able first to analyse" the world of the representations of the profession and the educator's training"(Ivi, p. 23). Representations, ideas and professional models to which each skill is anchored, and which allow each educator or the educators to reflect, to recognize herself and himself - even if necessary to change his way of living the profession - starting from the analysis and the explanation the way in which knowledge and skills are translated into the daily act of teaching, education and training.

So, in the preparation of an environment we have design and share models and implement techniques that allow to re-define the ability to tell, taking care of the metacognitive trajectories of the subject, investigating what is the autobiographical thought, questioning the thought processes, involving affective models, explaining the dynamics of values and all that is part of the subject in formation and constitutes his identity, even from the professional point of view.

"I believe that digital storytelling is a signature pedagogy of the 'New Humanities', engaging an interdisciplinary integration of critical thought and creative practice"(Benmayor, 2008, p. 188) states Rina Benmayor. secondary in addition, the same author, digital narratives represent a form of "Social pedagogy", since the process of creating digital stories asks for actions of sharing and exposing the narrated, in the context of a collaborative process (ibidem).

The case study here represented starts from our field research focused on the reflective practice and, in a particular way, through this analysis we want to analize the need in the educators training of the operative practice to focus better on the skills, adquired during the triennal degree and the $150 \mathrm{hs}$, that have to be on system with the self professional growing up.

So, in the Academic Year 2017/18 the research staff conducted a twentyhours workshops with 50 students in order to create a 3-5 minute digital stories on the personal representation of their 
personal, professional and educational choice of being a pedagogist. During the workshop (see the table 1) the researchers asks to the educators and future pedagogists to write and represent themselves, using the following suggestion:

The student wonders on his own history as an educator-pedagogist, reflecting on three fundamental aspects: cognitive, emotional and relational in a space-time arc that represents the 'who I am', 'who I am' and 'who I will be'. The digital storytelling must be represented by a video with a maximum duration of 3 minutes containing 9 transitions (authentic and personal photos/images). It should also contain the voice of the author and a representative background music. Everyone reflects on the moment in which he made the decision to continue his studies in a perspective that will see him as a protagonist of pedagogical actions.

In a 12 hs workshop our students work very hard to achieve the results we asked them. Here belove the protocol we use, summerized in the following table:

\begin{tabular}{|c|c|c|c|c|c|}
\hline & Content & $\begin{array}{l}\text { Participant } \\
\text { activities }\end{array}$ & Facilitator activities & $\begin{array}{l}\text { Assessment } \\
\text { of learning }\end{array}$ & Resources \\
\hline $\begin{array}{l}\text { Day } 1 \\
-2 \\
\text { hs }\end{array}$ & $\begin{array}{l}\text { Introduction } \\
\text { of the } \\
\text { Course }\end{array}$ & $\begin{array}{l}\text { Listen } \\
\text { Discuss }\end{array}$ & $\begin{array}{l}\text { Explain purpose of } \\
\text { programme - aims } \\
\text { \& overview }\end{array}$ & $\begin{array}{l}\text { Observation } \\
\text { Discussion } \\
\text { Time }\end{array}$ & $\begin{array}{l}\text { Programme } \\
\text { outline }\end{array}$ \\
\hline $\begin{array}{l}\text { Day } 1 \\
-1 \\
\text { hs }\end{array}$ & $\begin{array}{l}\text { Introduce } \\
\text { the } \\
\text { Instrument: } \\
\text { Sample } \\
\text { digital } \\
\text { stories }\end{array}$ & $\begin{array}{l}\text { Watch \& Listen } \\
\text { to the stories } \\
\text { Discuss impact }\end{array}$ & $\begin{array}{l}\text { Explain the } 7 \\
\text { Lambert's elements } \\
\text { \& the phases } \\
\text { process for the DST } \\
\text { design through the } \\
\text { analysis of the } \\
\text { samples }\end{array}$ & $\begin{array}{l}\text { Observation } \\
\text { Discussion }\end{array}$ & $\begin{array}{l}\text { Laptop \& } \\
\text { projector, } \\
\text { sample stories }\end{array}$ \\
\hline
\end{tabular}




\begin{tabular}{|c|c|c|c|c|c|}
\hline $\begin{array}{l}\text { Day } 1 \\
-2 \\
\text { hs }\end{array}$ & $\begin{array}{l}\text { Storyplannin } \\
\mathrm{g}\end{array}$ & $\begin{array}{l}\text { Write a } 100 \\
\text { words stories - } \\
\text { Time limit is } 30 \\
\text { minutes. } \\
\text { Students use } \\
\text { their artistic, } \\
\text { language, and } \\
\text { technical skills to } \\
\text { create digital } \\
\text { stories - the } \\
\text { story they want } \\
\text { to tell to the } \\
\text { community- } \\
\text { classroom } \\
\text { Each participant } \\
\text { reads out their } \\
\text { story to the } \\
\text { group, by } \\
\text { working } \\
\text { collectively, } \\
\text { learners are } \\
\text { practicing their } \\
\text { speaking and } \\
\text { negotiating } \\
\text { meaning }\end{array}$ & $\begin{array}{l}\text { Instruct the activity: } \\
\text { Write a story about } \\
\text { your story of } \\
\text { educator } \\
\text { Keep time \& remind } \\
\text { group as time limit } \\
\text { approaches } \\
\text { Explain the } \\
\text { importance of this } \\
\text { stage - creative } \\
\text { process } \\
\text { Lead the delivery of } \\
\text { the stories \& point } \\
\text { out how the } \\
\text { students start the } \\
\text { process of reflection } \\
\text { and introduce the } \\
\text { items they will find } \\
\text { in the rubric they } \\
\text { will use for the self } \\
\text { assessment } \\
\text { Thank participants } \\
\text { for their } \\
\text { contributions }\end{array}$ & $\begin{array}{l}\text { Presentatio } \\
\mathrm{n} \text { of stories }\end{array}$ & $\begin{array}{l}\text { Microsoft } \\
\text { Office: Word }\end{array}$ \\
\hline $\begin{array}{l}\text { Day } 2 \\
-2 \\
\text { hs }\end{array}$ & $\begin{array}{l}\text { Pre- } \\
\text { Production }\end{array}$ & $\begin{array}{l}\text { Select and } \\
\text { choose the } \\
\text { different media \& } \\
\text { organize it in the } \\
\text { storyboard }\end{array}$ & $\begin{array}{l}\text { Drive \& Point out } \\
\text { the students in a } \\
\text { critical use of } \\
\text { technologies } \\
\text { (ex: web watching }\end{array}$ & $\begin{array}{l}\text { Design the } \\
\text { the stories }\end{array}$ & $\begin{array}{l}\text { Use software } \\
\text { for } \\
\text { stopryboarding: } \\
\text { ComicLife, } \\
\text { Power Point }\end{array}$ \\
\hline
\end{tabular}




\begin{tabular}{|c|c|c|c|c|c|}
\hline & & & activity) & & \\
\hline $\begin{array}{l}\text { Day } 2 \\
-2 \\
\text { hs }\end{array}$ & Production & $\begin{array}{l}\text { Speak and } \\
\text { record the script } \\
\text { using an } \\
\text { accurate English, } \\
\text { listen the } \\
\text { recording and (if } \\
\text { not satisfied of } \\
\text { their } \\
\text { performance) re- } \\
\text { record the story } \\
\text { again to perfect } \\
\text { it } \\
\\
\text { They need to } \\
\text { practice their } \\
\text { narration and } \\
\text { work on their } \\
\text { oral production } \\
\text { (fluency, } \\
\text { intonation, } \\
\text { pronunciation). } \\
\text { As you need to } \\
\text { decide what } \\
\text { areas need } \\
\text { special attention } \\
\text { depending on } \\
\text { your learning } \\
\text { objectives. }\end{array}$ & $\begin{array}{l}\text { Drive \& Point out } \\
\text { the students in a } \\
\text { critical use of } \\
\text { technologies (ex: } \\
\text { use of open source } \\
\text { software) } \\
\text { Justify their choices } \\
\text { as an additional } \\
\text { speaking/critical } \\
\text { thinking activity }\end{array}$ & $\begin{array}{l}\text { Design the } \\
\text { the stories }\end{array}$ & $\begin{array}{l}\text { Use software } \\
\text { for the sound- } \\
\text { track: Audacity, } \\
\text { iMovie } \\
\text { Use Software } \\
\text { for photo- } \\
\text { retouch: Adobe } \\
\text { Photoshop }\end{array}$ \\
\hline
\end{tabular}




\begin{tabular}{|c|c|c|c|c|c|}
\hline $\begin{array}{l}\text { Day } 2 \\
-2 \\
\text { hs }\end{array}$ & $\begin{array}{l}\text { Post - } \\
\text { Production }\end{array}$ & $\begin{array}{l}\text { Mix all the } \\
\text { elements } \\
\text { together } \\
\text { following the } \\
\text { storyboarding } \\
\text { developed in the } \\
\text { pre-production } \\
\text { phase. } \\
\text { This is another } \\
\text { venue for } \\
\text { learners to } \\
\text { unleash their } \\
\text { creativity as they } \\
\text { mix images, and } \\
\text { add cool } \\
\text { transitions and } \\
\text { fun music to } \\
\text { their stories. }\end{array}$ & $\begin{array}{l}\text { Drive \& Point out } \\
\text { the students in a } \\
\text { critical use of } \\
\text { technologies (ex: } \\
\text { which software is } \\
\text { better to...) }\end{array}$ & $\begin{array}{l}\text { Design the } \\
\text { the stories }\end{array}$ & $\begin{array}{l}\text { Editing } \\
\text { software: } \\
\text { iMovie }\end{array}$ \\
\hline
\end{tabular}




\begin{tabular}{|c|c|c|c|c|c|}
\hline $\begin{array}{l}\text { Day } 3 \\
-2 \\
\text { hs }\end{array}$ & $\begin{array}{l}\text { Distribution } \\
\& \text { Discussion }\end{array}$ & $\begin{array}{l}\text { Assembly the } \\
\text { story } \\
\text { Share the story } \\
\text { Summarise key } \\
\text { learning }\end{array}$ & $\begin{array}{l}\text { Recap key learning } \\
\text { via Q\&A } \\
\text { ideally using a } \\
\text { computer projector } \\
\text { for other students to } \\
\text { watch and enjoy. If } \\
\text { you decide to } \\
\text { include assessment } \\
\text { in this project, we } \\
\text { would recommend } \\
\text { doing so informally } \\
\text { and avoiding } \\
\text { commenting on form } \\
\text { and structure during } \\
\text { or immediately after } \\
\text { presentations. In } \\
\text { fact, all aspects of } \\
\text { this activity are } \\
\text { based on a } \\
\text { communicative } \\
\text { approach where } \\
\text { focus is on process } \\
\text { as opposed to } \\
\text { product. } \\
\text { Re check that } \\
\text { everyone is happy } \\
\text { about their story } \\
\text { process \& } \\
\text { Thank participants } \\
\text { for their } \\
\text { contributions }\end{array}$ & $\begin{array}{l}\text { Q\&A } \\
\text { Evaluations }\end{array}$ & $\begin{array}{l}\text { Laptop\&Project } \\
\text { or }\end{array}$ \\
\hline
\end{tabular}

Table 2. syllabus for the DST laboratory

It is important to introduce briefly the tool and methodology we choose for the creation of the personal story. As the Digital Storytelling Association states "Digital Storytelling is the modern expression of the ancient art of storytelling. Throughout history, storytelling has been used share knowledge, wisdom, and values. Stories have taken many different forms. Stories have been adapted to each successive medium that has emerged, from the circle of the campfire to the silver screen, and now the computer screen." We can outline that a digital storytelling is an inttegrated story made up by text, images, music and voice, but moreover is a mean to spread up the potentiality of storytelling to know and understand the experiential world and imaginative of the 
workshop's partecipants and as Bruner states "storytelling was the original form of teaching, a powerful method to help students to make sense of the complex and unordered world of experience by crafting story lines"(Bruner 1997).

As the same way, the digital storytelling as a tool and additional data, help the researchers to exploit the potentiality of storytelling to know and understand the experiential world and imaginative of the participants.

The experience in a job context or around the world of job, narrated by students/educators or educators for example in the field of training, is not only an opportunity to apply theoretical knowledge acquired in the formal way of the university course. It also represents a moment of reflection through which the future pedagogists learns how to link what has been learned in the classrooms, on the books and in the so-called informal contexts, with the professional practice, even if controlled and defined by a training project.

In fact, if in general it can be said that the experiential component is fundamental in learning (see, for example, Malcolm Knowles, 1989, 1996), more specifically the traineeship, as claimed by Donald Schön $(1987,2006)$, is to be understood such as:

a setting designed for the purpose of learning a practice. In a context that is very close to the world of practice, students learn through doing, although their doing has a small impact on the work of the real world. They learn by means of pre-established projects that simulate and simplify the practice; or take part in projects in the real world, but under close supervision. Traineeship is a virtual world, relatively free of pressures, distractions and risks compared to the real world, despite referring to it. It is placed in the intermediate space between the world of practice, the "profane"world of ordinary life and the specialized world of academic knowledge (p.73).

We believe that the activity of storytelling in which people narrates the whole training activity is helpful to understand how to link the practical activity with the theoretical one, the experience in the field with what has been learned in formal learning contexts.

\section{A Self-assessment tool for the reflective educators: a co-designed rubric}

Using the digital storytelling in formative and evaluative key in the context of the university course and internship is a methodological choice that involves some preliminary reflections, some already expressed in the previous paragraphs. The first concerns the nature of the medium involved, the multimedia writing, the other concerns the critical self-assessment of the skills that in the our case will be carried out with the use of a rubric created specifically with the items described by Annacontini in paragraph 2 .

We debated the question related to writing that facilitates the neuralgic operation of distancing from the experience, which becomes visible and concrete, that is, becomes an object of reflection (Mortari, 2003). In this way, also through writing, one learns to distance himself from the trobles that characterizes the professions with high emotional involvement, such as the educational ones. As Fiamberti (2006) notes, "the operator writes to have a mirror (reflective need) and an embankment (containment need) in order to face complex situations in everyday life, also because they are emotionally involving"(p.3). The objectification of events made possible by writing is also facilitated by some intrinsic characteristics of the process of transforming facts into a digital 
storytelling. Storytelling, in fact, the words acquire a material consistency, they become permanent objects among which it is possible to identify links and connections that can escape. In particular, the narrative makes it possible to reconstruct, with different times and in different and not always predictable directions, the meaning of the experiences lived since it brings back and makes possible new realities (Bruner, 2006):

the narrative offers us, to give the name to an experience and also a ready and flexible means to deal with the uncertain results of our projects and our expectations. [...] thanks to the normalizing power of culture, our projeBut it is our narrative talent that gives us the ability to make sense of things when they do not have cts usually take place well and in complete tranquility. (pp. 31-32).

This makes clear the epistemic value of narrative thought as a thought that makes discoveries and knowledge possible. By taking care of human intentions, actions, vicissitudes and their results, it allows man to transform experience into shareable concepts.

In the final phase or in the final evaluation, in order to gather useful information to be able to make an overall balance of the experience told, we use a rubric containing the items, choosen and co-designed during the formal and reflective momenti in the classroom. The methodology is totally bottom-up and put the learner in the center of the process. The items are dialogued and shared with the storytellers and come up from real need of the self-assessment phase.

The most challenging aspect in the creation and production of an autobiographical digital storytelling is, as we said, constituted by the fact that it is not enough to retrace the experience and narrate it in the succession of events, but it is necessary to examine the path in critical terms, looking for to understand if and how much are the skills acquired, how they are functional to their path, if they are orientative for future professional and training choices.

So we designed a rubric, a measurement tool that sets the criteria for analyzing the most significant items abovementioned. The table clearly expresses the quality levels for each criterion considered useful, starting from minimum levels accepted. In our research the rubric is useful to to become a deeper tool to investigate self-evaluation and metacognition in the asset of personal, relational and professional skills (McTighe and Wiggins, 1999), it consists of: evaluation criteria, a defined scale and descriptive indicators to differentiate levels of understanding, skill and quality. These definitions guide us to the attribution of comparative score that tries to evaluate the performance of the storytellers based on a set of criteria that they range from a minimum to a maximum level (Danielson \& Hansen, 1999).

\begin{tabular}{|l|l|l|l|l|}
\hline Items & \multicolumn{3}{|l|}{ performance level } \\
\cline { 2 - 5 } & Excellent 4 & Good 3 & Tolerable 2 & Poor 1 \\
\hline Self-awareness & $\begin{array}{l}\text { During the } \\
\text { exercise of } \\
\text { storytelling I } \\
\text { was very sure } \\
\text { about myself, } \\
\text { my role, my } \\
\text { position. }\end{array}$ & $\begin{array}{l}\text { During the } \\
\text { excercise of } \\
\text { storytelling I } \\
\text { was sure about } \\
\text { myself, my } \\
\text { role, my } \\
\text { position. }\end{array}$ & $\begin{array}{l}\text { During the } \\
\text { excercise of } \\
\text { storytelling I was } \\
\text { quite sure about } \\
\text { myself, my role, } \\
\text { my position. }\end{array}$ & $\begin{array}{l}\text { During the } \\
\text { excercise of } \\
\text { storytelling I } \\
\text { was lost myself, } \\
\text { I did not } \\
\text { recognize my } \\
\text { role and my }\end{array}$ \\
\hline
\end{tabular}




\begin{tabular}{|c|c|c|c|c|}
\hline & & & & position. \\
\hline $\begin{array}{l}\text { Recognition of } \\
\text { emotions }\end{array}$ & $\begin{array}{l}\text { During the } \\
\text { exercise of } \\
\text { storytelling I } \\
\text { was able to } \\
\text { recognize } \\
\text { every } \\
\text { emotions I } \\
\text { felt, positive } \\
\text { and negative } \\
\text { ones. }\end{array}$ & $\begin{array}{l}\text { During the } \\
\text { exercise of } \\
\text { storytelling I } \\
\text { was able to } \\
\text { recognize } \\
\text { some emotions } \\
\text { i felt, positive } \\
\text { and negative } \\
\text { ones. }\end{array}$ & $\begin{array}{l}\text { During the } \\
\text { exercise of } \\
\text { storytelling I was } \\
\text { able to recognize } \\
\text { few emotions I } \\
\text { felt, positive and } \\
\text { negative ones. }\end{array}$ & $\begin{array}{l}\text { During the } \\
\text { exercise of } \\
\text { storytelling I } \\
\text { was totally } \\
\text { disoriented. }\end{array}$ \\
\hline $\begin{array}{l}\text { Management of } \\
\text { emotions }\end{array}$ & $\begin{array}{l}\text { During the } \\
\text { exercise of } \\
\text { storytelling I } \\
\text { was able to } \\
\text { manage the } \\
\text { emotions I } \\
\text { felt and } \\
\text { mantain a } \\
\text { high } \\
\text { performance. }\end{array}$ & $\begin{array}{l}\text { During the } \\
\text { exercise of } \\
\text { storytelling I } \\
\text { was able to } \\
\text { manage the } \\
\text { emotions I felt } \\
\text { and mantain a } \\
\text { good } \\
\text { performance. }\end{array}$ & $\begin{array}{l}\text { During the } \\
\text { exercise of } \\
\text { storytelling I was } \\
\text { cannot manage } \\
\text { all the emotions I } \\
\text { felt and mantain } \\
\text { a good } \\
\text { performance. }\end{array}$ & $\begin{array}{l}\text { During the } \\
\text { exercise og } \\
\text { storytelling I } \\
\text { was totally upset } \\
\text { and disoriented. }\end{array}$ \\
\hline Neoteny & $\begin{array}{l}\text { The exercise } \\
\text { of storytelling } \\
\text { helped me to } \\
\text { realize I } \\
\text { strongly } \\
\text { believed to } \\
\text { improve my } \\
\text { personal and } \\
\text { professional } \\
\text { life. }\end{array}$ & $\begin{array}{l}\text { The exercise of } \\
\text { storytelling } \\
\text { helped me to } \\
\text { realize I } \\
\text { believed to } \\
\text { improve my } \\
\text { personal and } \\
\text { professional } \\
\text { life. }\end{array}$ & $\begin{array}{l}\text { The exercise of } \\
\text { storytelling } \\
\text { helped me to } \\
\text { realize I not so } \\
\text { convinced to } \\
\text { improve my } \\
\text { personal and } \\
\text { professional life. }\end{array}$ & $\begin{array}{l}\text { I could not } \\
\text { hange or } \\
\text { improve nothing. }\end{array}$ \\
\hline Locus of control & $\begin{array}{l}\text { During the } \\
\text { storytelling I } \\
\text { was aware to } \\
\text { determine all } \\
\text { the close } \\
\text { links between } \\
\text { my personal } \\
\text { actions or } \\
\text { decisions and } \\
\text { the events of }\end{array}$ & $\begin{array}{l}\text { During the } \\
\text { storytelling I } \\
\text { was quite } \\
\text { aware to } \\
\text { determine } \\
\text { some links } \\
\text { between my } \\
\text { personal } \\
\text { actions or } \\
\text { decisions and }\end{array}$ & $\begin{array}{l}\text { During the } \\
\text { storytelling I } \\
\text { understand that } \\
\text { there could be a } \\
\text { correlations } \\
\text { between my } \\
\text { personal actions } \\
\text { or decisions and } \\
\text { the events of my } \\
\text { life. }\end{array}$ & $\begin{array}{l}\text { It is difficult for } \\
\text { me to exlpain } \\
\text { the possibility of } \\
\text { a link between } \\
\text { my action and } \\
\text { the events of my } \\
\text { life. }\end{array}$ \\
\hline
\end{tabular}




\begin{tabular}{|c|c|c|c|c|}
\hline & my life. & $\begin{array}{l}\text { the events of } \\
\text { my life. }\end{array}$ & & \\
\hline Stability & $\begin{array}{l}\text { During the } \\
\text { storytelling I } \\
\text { realized I lead } \\
\text { all the past } \\
\text { events of my } \\
\text { story. }\end{array}$ & $\begin{array}{l}\text { During the } \\
\text { storytelling I } \\
\text { realized how } \\
\text { could I lead all } \\
\text { the past } \\
\text { events of my } \\
\text { story. }\end{array}$ & $\begin{array}{l}\text { During the } \\
\text { storytelling I } \\
\text { realized that the } \\
\text { instability of } \\
\text { some events } \\
\text { made me } \\
\text { unconfortable } \\
\text { and not the lead } \\
\text { of my life. }\end{array}$ & $\begin{array}{l}\text { During the } \\
\text { storytelling I } \\
\text { was not able to } \\
\text { face up the } \\
\text { instability of the } \\
\text { events of my life } \\
\text { and this made } \\
\text { me confused. }\end{array}$ \\
\hline Handle the failure & $\begin{array}{l}\text { During the } \\
\text { storytelling I } \\
\text { realized how I } \\
\text { was able to } \\
\text { manage the } \\
\text { fail moment } \\
\text { of my life and } \\
\text { re-act fully } \\
\text { believing that } \\
\text { every I could } \\
\text { re-start in a } \\
\text { positive way. }\end{array}$ & $\begin{array}{l}\text { During the } \\
\text { storytelling I } \\
\text { realized how I } \\
\text { was able to } \\
\text { understand the } \\
\text { fail moments } \\
\text { of my life but I } \\
\text { was not able } \\
\text { to re-act } \\
\text { immediately. }\end{array}$ & $\begin{array}{l}\text { During the } \\
\text { storytelling I } \\
\text { realized how I } \\
\text { was not able to } \\
\text { manage the fail } \\
\text { moments of my } \\
\text { life but I believed } \\
\text { that I could re- } \\
\text { start in a such } \\
\text { way. }\end{array}$ & $\begin{array}{l}\text { It was very } \\
\text { difficoult for me } \\
\text { to understand } \\
\text { and manage the } \\
\text { fail moment. I } \\
\text { felt astonished. }\end{array}$ \\
\hline Previsional skills & $\begin{array}{l}\text { When I wrote } \\
\text { my story I } \\
\text { could } \\
\text { describe my } \\
\text { future choice } \\
\text { and I had } \\
\text { clear ideas. }\end{array}$ & $\begin{array}{l}\text { When I wrote } \\
\text { my story I } \\
\text { could describe } \\
\text { my future } \\
\text { choice but I } \\
\text { had no ideas } \\
\text { about the way } \\
\text { to reach my } \\
\text { aims. }\end{array}$ & $\begin{array}{l}\text { When I wrote my } \\
\text { story I had some } \\
\text { doubts about my } \\
\text { future choice and } \\
\text { the way to reach } \\
\text { my aims. }\end{array}$ & $\begin{array}{l}\text { When I wrote } \\
\text { my story I was } \\
\text { totally confused } \\
\text { about my future } \\
\text { choice but I had } \\
\text { no ideas about } \\
\text { the way to reach } \\
\text { my aims. }\end{array}$ \\
\hline Intellectualization & $\begin{array}{l}\text { When I did } \\
\text { the excercise } \\
\text { of storytelling } \\
\text { I was able to } \\
\text { understand } \\
\text { and name } \\
\text { every } \\
\text { troubled } \\
\text { situations of } \\
\text { my life and }\end{array}$ & $\begin{array}{l}\text { When I did the } \\
\text { excercise of } \\
\text { storytelling I } \\
\text { was able to } \\
\text { understand } \\
\text { and name } \\
\text { some troubled } \\
\text { situations of } \\
\text { my life. }\end{array}$ & $\begin{array}{l}\text { When I did the } \\
\text { excercise of } \\
\text { storytelling I was } \\
\text { able to } \\
\text { understand but } \\
\text { not to name } \\
\text { every troubled } \\
\text { situations of my } \\
\text { life. }\end{array}$ & $\begin{array}{l}\text { When I did the } \\
\text { excercise of } \\
\text { storytelling I } \\
\text { was not able to } \\
\text { understand and } \\
\text { name every } \\
\text { troubled } \\
\text { situations of my } \\
\text { life. }\end{array}$ \\
\hline
\end{tabular}




\begin{tabular}{|c|c|c|c|c|}
\hline Self efficacy & $\begin{array}{l}\text { When I wrote } \\
\text { my story, I } \\
\text { had the full } \\
\text { perception of } \\
\text { my skills to } \\
\text { perform my } \\
\text { role. I fully } \\
\text { distinguished } \\
\text { between the } \\
\text { effectiveness } \\
\text { of personal } \\
\text { expectations } \\
\text { and my } \\
\text { outcome of } \\
\text { expectations. }\end{array}$ & $\begin{array}{l}\text { When I wrote } \\
\text { my story, I } \\
\text { had the } \\
\text { perception of } \\
\text { my skills to } \\
\text { perform my } \\
\text { role but I did } \\
\text { not know if } \\
\text { they are the } \\
\text { right ones for } \\
\text { the } \\
\text { effectiveness } \\
\text { of personal } \\
\text { expectations } \\
\text { and my } \\
\text { outcome of } \\
\text { expectations. }\end{array}$ & $\begin{array}{l}\text { When I wrote my } \\
\text { story, I was } \\
\text { confused about } \\
\text { my skills and the } \\
\text { performance in } \\
\text { my role, I try to } \\
\text { understand the } \\
\text { effectiveness of } \\
\text { personal } \\
\text { expectations and } \\
\text { my outcome of } \\
\text { expectations }\end{array}$ & $\begin{array}{l}\text { When I wrote } \\
\text { my story, I was } \\
\text { totally confused } \\
\text { bout my skills } \\
\text { and my } \\
\text { performance. }\end{array}$ \\
\hline
\end{tabular}

Table 3. self assessment rubric

The act of narration should constitute a moment in which the storyteller distances himself from his experience by making it conscious and re-presents it in such a way as to transform it into shareable and reusable meanings. As Luigina Mortari (2009, p. 58) states, referring to Gadamer's hermeneutic theory, the subject, experiencing a collision with the object of investigation, is forced to elaborate new way of interpretation that overcome the conditioning imposed by the precomprehensions of his own cognitive process, arriving at an "adequate understanding of the object". It is precisely in this horizon that the narrative method represents a very useful opportunity to achieve a greater and more effective understanding of the experience that, interacting with the knowledge and skills already possessed, determines a growth of shared meanings.

\section{Assessment process and conclusion}

After the analysis, collection and production phase of the contents, the participants

were invited to present the work in the debriefing phase. The debriefing was created on the dual side of the partecipants (peer and self assessment) and teachers (teacher assessment) through free brainstorming. Evaluation activities took place on two levels:

a. peer and self assessment development of critical skills through the reflexivity and reflection on the production stage.

b. teacher assessment appreciation of product works correction of possible misconceptions and general discussion on the phase of teaching activity. 
Even if the didactic laboratory realized did not require a formal assessment of learning, the activities being debriefed no time for a shared assessment is provided. In particular, after having shown the materials produced, the groups tried to exchange feedback in the perspective of peer assessment and self assessment.

Such methods of evaluation favors the development of metacognitive and self reflexive skills in a lifelong learning perspective they promote the empowerment of the subjects involved (McConnell, 2002), and therefore the form responsible and thoughtful professionals.

The DST experience, in short, involved the participants in a sequence of activities that can be summed up as follows:

1. Design of the story and processing of the storyboard in the classroom

2. Search for online and offline materials

3. Assembly of elements in multimedia format

4. Share the stories with other partecipants

5. Compare of processing and reflection on activities

And, at last, thanks to the use of the rubric a process of self-reflection was activated allowing the participants to stop and analyze, through the specific items, aspects of their daily life by exploring different dimensions.

Furthermore, the activities were collected collaboratively, with the creation of action of working groups, heterogeneous in terms of competence in relation to use of the media, for previous knowledge and experience in relation to digital communication.

During the debriefing the students, thanks to the technique of the Answer \& Question, the constructive exchange of opinions that represented formative feedback in a constructive and sharing perspective was favored. The moment of assessment was carried out as a training process and to participate that represented an added value of the educational laboratory as well as an action of self-orientation and metacognition.

\section{References}

Altet M. (1994). La formation professionnelle des enseignants. Paris. PUF.

Annacontini G. (2017), «S'opposer sans se massacrer»: uscire dal vicolo cieco della contemporaneità. In S. Ulivieri (a cura di), Le emergenze educative della società contemporanea. Progetti e proposte per il cambiamento, Lecce. PensaMultimedia, pp. 9-14.

Anolli L., Legrenzi P. (2001). Psicologia generale Bologna. Il Mulino.

Baldacci M. (2014). La mente proteiforme. Un nuovo orizzonte formativo. In G. Annacontini R. Gallelli (a cura di). Formare altre(i)menti. Bari. Progedit.

Baldacci M. (2016). La prassi educativa. In M. Baldacci, E. Colicchi (a cura di). Teoria e prassi in educazione. Questioni epistemologiche. Roma. Carocci.

Bandura, A. (1986). Social foundations of thought and action. Englewood Cliffs, NJ, 1986.

Bandura A. (1986a). The explanatory and predictive scope of self-efficacy theory. J Soc Clin Psychol. 4, 3, pp. 359-373. 
Bandura A. (1986b). Social Foundations of Thought and Action: A Social Cognitive Theory. Englewood Cliffs, New Jersey. Prentice-Hall.

Bandura, A. (2001), Guida alla costruzione delle scale di autoefficacia. In Caprara G. V. (a cura di), La valutazione dell'autoefficacia. Trento. Erickson.

Batini F. Del Sarto G. (2007). Raccontare storie. Roma. Carocci.

Benmayor, R. (2008). Digital storytelling as a signature pedagogy for the new humanities. Arts and Humanities in Higher Education, 7(2), 188-204.

Bennet-Goleman T. (2001). Alchimia emotiva. Come la mente può curare il cuore. Milano. Rizzoli.

Bertin G. M. (1987). Ragione proteiforme e demonismo educativo. Scandicci. La Nuova Italia.

Boud D., Keogh R., Walker D. (Eds.) (1985). Reflection: turning experience into learning. London: Kogan Page.

Broussard S. C., Garrison M. E. B. (2004). The relationship between classroom motivation and academic achievement in elementary school-aged children. Family and Consumer Sciences Research Journal, 33, 2, pp. 106-120.

Bruner, J. S. (1997). The culture of education. Harvard University Press.

Bruner, J. S., Gómez Crespo, J. C., \& Linaza, J. L. (2006). Actos de significado: más allá de la revolución cognitiva. Alianza, Madrid

Bruscaglioni M. (1994). La società negata. Milano. FrancoAngeli.

Calvani, A. (2011). «Decision Making» nell'istruzione. «Evidence Based Education» e conoscenze sfidanti. Journal of Educational, Cultural and Psychological Studies (ECPS Journal), 2(3), 77-99.

Cambi, F. (2006). Incontro e dialogo. Roma, Carocci.

Cassani, E. C., \& Fontana, A. (2000). L'autobiografia in azienda: metodologie per la ricerca e l'attività formativa. Guerini e Associati.

Colli G. (1992). La nascita della filosofia. Milano. Adelphi.

Danielson, C., \& Hansen, P. (1999). A Collection of Performance Tasks and Rubrics: Primary School Mathematics. Eye on Education, 6 Depot Way West, Suite 106, Larchmont, NY 10538.

Dato D. (2004) A scuola di emozioni. Bari. Progedit.

Dewey J. (1965). Come pensiamo. Firenze. La Nuova Italia.

Duval S., Wicklund R. A. (1972). A theory of objective self-awareness. New York. Academic Press.

Fiamberti, C. (2006). La documentazione professionale dall'autoriflessione alla progettualità. Rivista di servizio sociale, 2.

Flammer A. (1995). Developmental analysis of control beliefs. In A. Bandura (ed.), Self-efficacy in changing societies. New York. Cambridge University Press, pp. 69-113.

Gadamer H. G. (2001). Verità e metodo. Milano. Bompiani.

Gardner H. (1983). La nuova scienza della mente. Storia della rivoluzione cognitiva. Milano. Feltrinelli.

Gardner H., Hatch T. (1989). Educational implications of the theory of multiple intelligences. Educational Researcher, 18, 8, pp. 4-10.

Goleman D. (1997). Intelligenza emotiva. Milano. Rizzoli.

Goodman, N. D. (1979). Mathematics as an objective science. The American Mathematical Monthly, $86(7), 540-551$.

Gould S. J. (2013). Ontogenesi e filogenesi. Milano-Udine. Mimesis.

Guay F., Chanal J., Ratelle C. F., Marsh H. W., Larose S., Boivin, M. (2010). Intrinsic, identified, and controlled types of motivation for school subjects in young elementary school children. British Journal of Educational Psychology, 80, 4, pp. 711-735. 
Harris P. L. (1991), Il bambino e le emozioni. Milano. Cortina.

Harris P.L., Olthof T., Meerum Terwogt M. (1981). Children's knowledge of emotion. Journal of Child Psychology and Psychiatry, 22, pp. 247-261.

Herrmann D., Raybeck D. Gruneberg M. (2002). Imporving memory and study skills. Advances in theory and practice. Ashland. Hogrefe \& Huber Publishers.

Holborn P., Wideen M., Andrews (Eds.) (1992). Devenir enseignant, à la conquête de l'identité professionnelle. Montréal. Ėditions Logiques.

Knowles, M. (1996). Adult learning. The ASTD Training and Development Handbook.

Lazarus R. S., Folkman, S. (1984). Stress, Appraisal, and Coping. New York: Springer.

McConnell, D. (2002). The experience of collaborative assessment in e-learning.

Studies in Continuing Education, 23(1), 73-92.

McTighe, J., Seif, E., \& Wiggins, G. (2004). You can teach for meaning. Educational Leadership, 62(1), 26-30.

Mead G. H. (1972). Mente sé e società. Firenze. Giunti-Barbera.

Mezirow, J. (2003). Apprendimento e trasformazione. Milano: Raffaello Cortina

Morin E. (1974). L'evento sfinge, in AA.VV. Teorie dell'evento. Milano. Bompiani.

Morin E. (2001). Il paradigma perduto. Che cos'è la natura umana?. Milano. Feltrinelli.

Morin A. (2011). Self-Awareness Part 1: Definition, Measures, Effects, Functions, and Antecedents. Social and Personality Psychology Compass 5/10, pp. 807-823, doi: 10.1111/j.17519004.2011.00387.x.

Mortari, L. (2003). Apprendere dall'esperienza: il pensare riflessivo nella formazione. Roma, Carocci editore.

Paquay, L. (2006). Formare gli insegnanti professionisti. Quali strategie? Quali competenze?. Armando Editore.

Perkins, D. N., \& Salomon, G. (1989). Are cognitive skills context-bound?. Educational researcher, 18(1), 16-25.

Perrenoud P. (2001). Développer la pratique réflexive dans le métier d'enseignant. Paris. ESF.

Polanyi M. (1990). La conoscenza personale. Verso una filosofia post-critica. Milano. Rusconi.

Pons F. e Doudin P.-A, (2000), Niveaux de coscience et développment: entre métacognition et métaémotion, in C. Vogel, E. Thommen (a cura di), Lire les passions, Berne, Peter Land.

Pons F. e Harris P. L. (2000), Test of Emotion Comprehension, Oxford, Oxford University Press.

Richburg M., Fletcher T. (2002). Emotional Intelligence: directing a child's emotional education. Child Study Journal, 32, pp. 32-38.

Rodgers C. (2002). Defining Reflection: Another Look at John Dewey and Reflective Thinking. Teacher College Record, 104, 4, June, pp. 842-866.

Rossi B. (2011). L'organizzazione educativa. La formazione nei luoghi di lavoro. Roma. Carocci.

Saarni C. (1999). The development of emotional competence. New York. The Guilford Press

Saint-Arnaud Y. (1992). Connaître par l'action. Montréal. Presses de I'Université de Montréal.

Savikas M. L. (2014). Career counseling. Guida teorica e metodologica per il XXI secolo. Trento. Erickson.

Scaratti G., Stoppini L., Zucchermaglio C. (2009), Autori di ambienti organizzativi. Costruire le proprie pratiche lavorative. Roma. Carocci.

Schön, D. A. 1983. The Reflective Practitioner: how professionals think in action, New York: Basic Books.

Schön, D. (1993). Il professionista riflessivo. Per una nuova epistemologia della pratica professionale. Bari. Dedalo. 
Shapiro L. E. (1998). How to raise a child with high EQ. A parent's guide to emotional intelligence. New York. Harper Collins.

Vygotsky, L. S. 1978. Mind in society: The development of higher psychological processes, Cambridge, MA: Harvard University Press.

Wald J., Taylor S., Asmundson G. J. G., et al. (2006). Literature review of concepts: psychological resiliency. Toronto (ON). Defence R\&D.

Weiner B. (1985). An Attributional Theory of Achievement Motivation and Emotion. In Pshicological Review, 92, pp. 548-573.

Zonca P. (2004) Persona e progetto. Torino. SEI. 